\title{
Early Cretaceous trypanosomatids associated with fossil sand fly larvae in Burmese amber
}

\author{
George Poinar Jr \\ Department of Zoology, Oregon State University, Corvallis, OR 97331, US
}

Early Cretaceous flagellates with characters typical of trypanosomatids were found in the gut of sand fly larvae, as well as in surrounding debris, in Burmese amber. This discovery supports a hypothesis in which freeliving trypanosomatids could have been acquired by sand fly larvae in their feeding environment and then carried transtadially into the adult stage. At some point in time, specific genera were introduced into vertebrates, thus establishing a dixenous life cycle.

Key words: Cretaceous - sand fly larvae - trypanosomatids

While trypanosomatids probably existed in the Paleozoic and free-living forms were probably more diverse in the past than today, Paleoleismania proterus Poinar \& Poinar (2004a, b) in the Burmese amber sand fly, Palaeomyia burmitis Poinar (2004), shows that sand flies were already transmitting trypanosomatids to vertebrates some 100 million years ago (mya). Attempts have been made to find fossils which show how sand flies may have originally acquired ancient trypanosomatids. Such evidence, which was obtained in a piece of Burmese amber containing two late-instar sand fly larvae, is presented here.

\section{MATERIALS AND METHODS}

The amber piece containing the fossil sand fly larvae is semicircular in outline, measuring $13 \mathrm{~mm}$ along the longest side, $9 \mathrm{~mm}$ wide, $4 \mathrm{~mm}$ deep, and weighs $0.4 \mathrm{~g}$. Observations, drawings, and photographs were made with a Nikon SMZ-10 R stereoscopic microscope and Nikon Optiphot compound microscope with magnifications up to $1000 x$. Measurements were obtained by means of a microscopic ocular grid calibrated in microns. The amber piece containing the fossils is deposited in the Poinar amber collection (accession \# B-D-24) maintained at Oregon State University.

Amber from Burma occurs in lignitic seams in sandstone-limestone deposits in the Hukawng Valley, southwest of Maingkhwan in the state of Kachin $\left(26^{\circ} 20^{\prime} \mathrm{N}\right.$, $\left.96^{\circ} 36^{\prime} \mathrm{E}\right)$. Palynomorphs obtained from the amber beds have been assigned to the Upper Albian ( 100-105 mya) of the Early Cretaceous (Cruickshank \& Ko 2003). Nuclear magnetic resonance and the structure of wood fibers found embedded in the amber showed that the tree source of Burmese amber is a member of the Araucariaceae, probably Agathis (Poinar et al. 2007).

E-mail: poinarg@science.oregonstate.edu

Received 5 March 2007

Accepted 13 June 2007

\section{RESULTS}

The amber piece contains two sand fly larvae and several fruiting bodies of a coral mushroom (Poinar \& Brown 2003, Poinar et al. 2006) (Fig. 1). Both sand fly larvae had voided some of their intestinal contents at the time of preservation, which is typical behavior of mature sand fly larvae just before pupation (Lawyer \& Perkins 2000). Both of the larvae also had debris from the feeding substrate, probably the fruiting bodies of the coral mushroom, attached to portions of their bodies. Associated with the expelled fecal matter as well as in the debris attached to the cuticles of both sand flies, were numerous flagellates orientated in a myriad of directions and planes. Similar flagellates surrounded the bases of the fungal fruiting bodies. In order to ascertain whether flagellates were also inside the gut of the sand fly larvae, a portion of the alimentary tract of one of the sand flies was exposed by further polishing of the amber. This revealed the presence of numerous flagellates in the larval mid gut (Fig. 2). The flagellates had been naturally fixed and stained due to chemical properties of the resin and showed dense inner areas corresponding to nuclei and kinetoplasts (Figs 3, 4). The great majority of flagellates resembled promastigotes since they had kinetoplasts located in the anterior end (Figs 3-5). Their sizes were $(\mathrm{N}=17)$ : mean length $=11.0 \pm 4.1 \mu \mathrm{m}$; mean width $=1.2 \pm 0.2 \mu \mathrm{m}$; flagella length $=6.0 \pm 2.2$. No aflagellated cells were observed.

\section{DISCUSSION}

The presence of a kinetoplast and a single flagella places these flagellates in the family Trypanosomatidae (Vickerman 2000). It was not possible to determine the genus, however the position of the nucleus in relation to the kinetoplast is similar to promastigotes of Leptomonas. Members of this genus have been reported from adult sand flies (Warburg 1991, Sousa et al. 1998a, b) and some species show a close relationship to Leishmania (Yurchenko et al. 2006). However, some of the fossil flagellates could be epimastigotes or opisthomastigotes, flagellate types also occurring in adult sand flies (McConnel \& Correa 1964, Wallace \& Hertig 1968).

This discovery shows that Early Cretaceous sand fly larvae developed in habitats containing free-living flagel- 


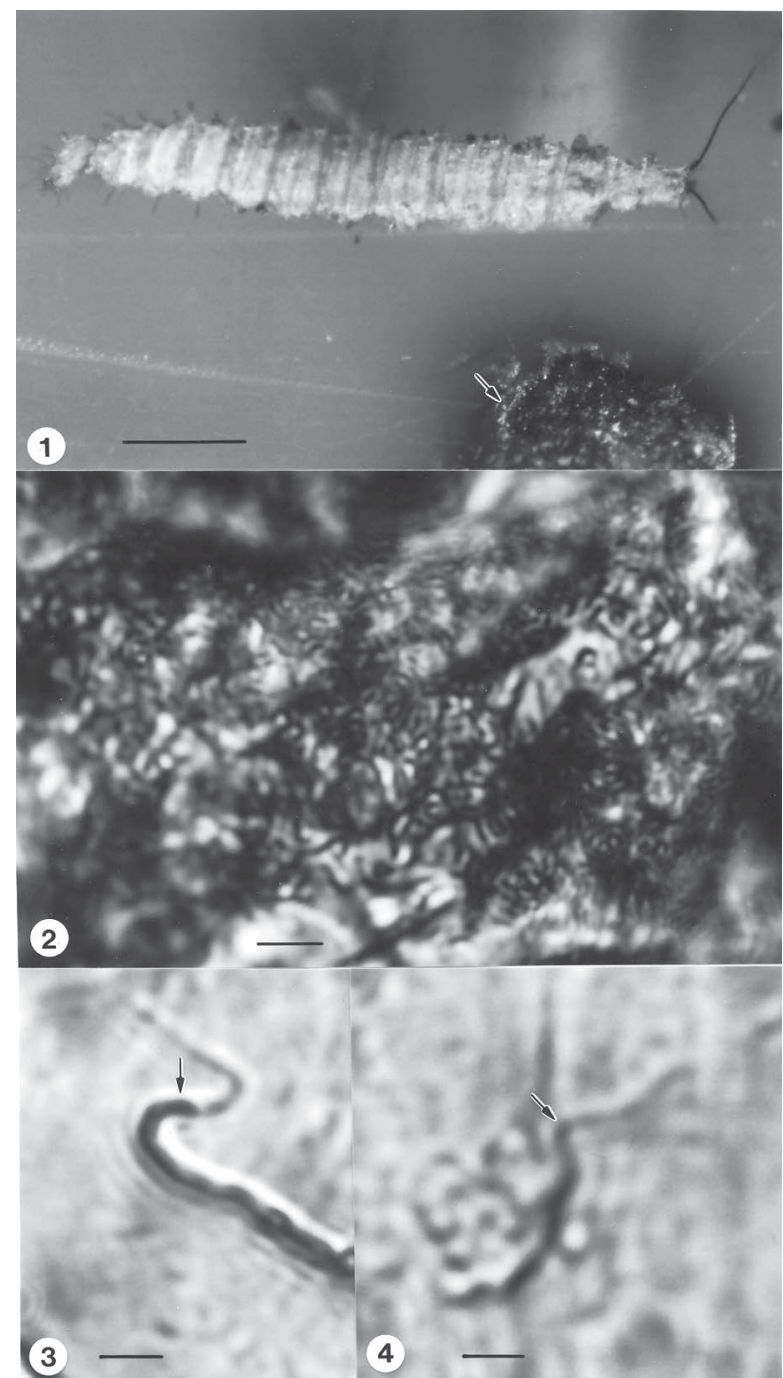

Figs 1-4 - 1: one of the Early Cretaceous sand fly larvae adjacent to a fruiting body (arrow) of the coral mushroom, Palaeoclavaria burmitis, in Burmese amber. Specimen photographed prior to polishing away part of the body to reveal the gut contents. Bar $=530 \mu \mathrm{m} ; 2$ : flagellates inside the alimentary tract of the Early Cretaceous sand fly larva shown in Fig. 1. Bar $=7 \mu \mathrm{m} ; 3$ : flagellate adjacent to sand fly larva in Early Cretaceous amber. Arrow $=$ putative kinetoplast. $\mathrm{Bar}=2 \mu \mathrm{m} ; 4$ : flagellates adjacent to a fruiting body of a coral mushroom in Early Cretaceous amber. Arrow = putative kinetoplast. $\mathrm{Bar}=2 \mu \mathrm{m}$.

lates with characters of trypanosomatids and that these flagellates were ingested by and probably multiplied inside sand fly larvae. It is possible that these flagellates were carried through the pupal and into the adult stage, thus showing how adult sand flies could have originally acquired trypanosomatids. Once in an adult sand fly, the flagellates could be transmitted to a vertebrate, thus establishing a continuing cycle between vectors and vertebrates.

The above theory of larval acquisition of free-living trypanosomatids, their transfer into adults and then into vertebrates, is supported by molecular studies showing that insects were the first hosts to harbor trypanosomatids (Simpson et al. 2006). Further support for this

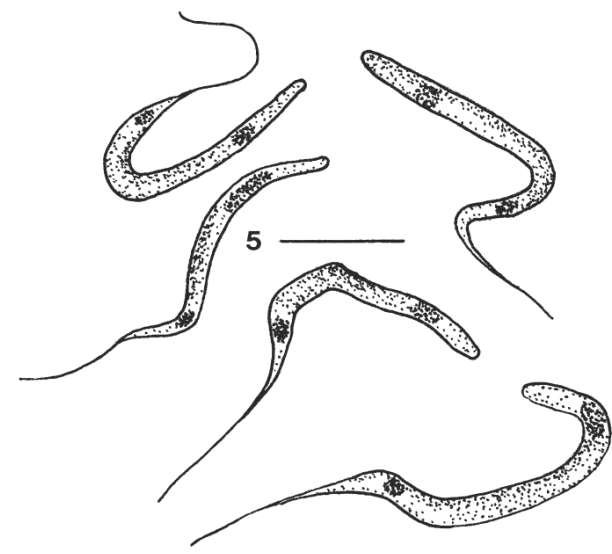

Fig. 5: flagellates associated with sand fly larvae in Early Cretaceous amber. $\mathrm{Bar}=4 \mu \mathrm{m}$.

theory are studies showing the habitat versatility of freeliving trypanosomatids. Species of the lower Trypanosomatidae in the genera Leptomonas and Herpetomonas, which are normally gut inhabitants of insects, have been reported parasitizing humans (Schnur et al. 1992, Jimenez et al. 1996, Pacheco et al. 1998, Sousa et al. 1998a, b).

Using molecular techniques, a trypanosomatid isolated from Egyptian rats was determined to be closely related to Herpetomonas ztiplika, a gut inhabitant of a blood-sucking biting midge (Diptera: Ceratopogonidae). It was suggested that this flagellate could have been transferred to the vertebrate by the insect during blood feeding and is in the process of adapting to mammals (Podlipaev et al. 2004).

Some trypanosomatids inhabiting the alimentary tracts of insects can be found free-living in the immediate environment today. Species of Crithidia normally found in mosquitoes (Diptera: Culicidae) undergo a freeliving stage in water and Herpetomonas spp. infecting fruit flies (Diptera: Drosophilidae), scuttle flies (Diptera: Phoridae), and muscid flies (Diptera: Muscidae) all occur in the larval habitats (McGhee \& Cosgrove 1980).

There are records of flagellates and bacteria being passed transtadially in sand flies and other insects. Transtadial transmission of the trypanosomatid, Crithidia fasciculata Leger, was experimentally achieved in the mosquito, Culiseta incidens (Thompson) (Clark et al. 1964) and bacteria were shown to be transmitted transtadially from larval to adult Phlebotomus duboscqi (Volf 2002). The trypanosomatid, Leptomonas ctenocephali (Fantham) is carried through the pupal stage into the adult dog flea, Ctenocephalides canis (Curtis) and when mealworm larvae were experimentally infected with Leptomonas pyrrhocoris L.\& D. they carried the flagellates though the pupal and into the adult stage (Steinhaus 1949).

The scenario of larvae acquiring free-living flagellates and carrying them over to the adult stage may have occurred many times in the past. However the chances that a particular flagellate could avoid the vertebrate 
immune system, reproduce inside the vertebrate and then be acquired by a subsequent sand fly, were probably slight. We may never know the exact combination of confluent events that resulted in the successful transfer of free-living trypanosomatids into sand flies and subsequently vertebrates. When such an event did occur, it would have represented a novel infection and could have resulted in outbreaks of epidemic proportions. This is supported by the discovery that 10 out of 21 female sand flies in Burmese amber were infected with trypanosomatids, which is an infection rate of nearly $50 \%$ and suggests that Paleoleishmania had reached epidemic proportions in the Burmese amber forest 100 mya.

\section{ACKNOWLEDGEMENTS}

To RL Jacobson for providing references and comments on an earlier draft of this manuscript. To Roberta Poinar for improving the manuscript.

\section{REFERENCES}

Clark RB, Kellen WR, Lindegren JE, Smith TW 1964. The transmission of Crithidia fasiculata Leger 1902 in Culiseta incidens (Thomson). J Protozool 11: 400-402.

Cruickshank RD, Ko K 2003 Geology of an amber locality in the Hukawng Valley, northern Myanmar. J Asian Earth Sci 21: 441-455.

Jimenez MI, Lopez-Velez R, Molina R, Canavete C, Alvar J 1996. HIV co-infection with a currently non-pathogenic flagellate. Lancet 347: 264-265.

Lawyer PG, Perkins PV 2000. Leishmaniasis and trypanosomiasis. In BF Eldridge, JD Edman, Medical Entomology, Kluwer Academic Publishers, Dordrecht, p. 231-298.

McConnel E, Correa M 1964. Trypanosomes and other microorganisms from Panamanian Phlebotomus sandflies. $J$ Parasitol 50: 523-528.

McGhee RB, Cosgrove WB 1980. Biology and physiology of the lower Trypanosomatidae. Microbiol Rev 44: 140-173.

Pacheco RS, Marzochi, MCA, Pires MQ, Brito CMM, Madeira MD, Barbosa Santos EGO 1998. Parasite genotypically related to a monoxenous trypanosomatid of dog's flea causing opportunistic infection in an HIV positive patient. Mem Inst Oswaldo Cruz 93: 531-537.

Podlipaev SA, Sturm NR, Fiala I, Fernandes O, Westenberger SJ, Dollet M, Campbell DA, Lukes J 2004. Diversity of insect trypanosomatids assessed from the Spliced Leader RNA and 5S rRNA Genes and Intergenic Regions. J Eukary Microbiol 51: 283-290.

Poinar Jr GO 2004. Palaeomyia burmitis (Diptera: Phlebotomidae), a new genus and species of Cretaceous sand flies with evidence of blood-sucking habits. Proc Entomol Soc Washington 106: 598-605.
Poinar Jr GO, Brown AE 2003. A non-gilled hymenomycete in Cretaceous amber. Mycol Res 107: 763-768.

Poinar Jr GO, Poinar R 2004a. Paleoleishmania proterus n. gen., n. sp., (Trypanosomatidae: Kinetoplastida) from Cretaceous Burmese amber. Protista 155: 305-310.

Poinar Jr GO, Poinar R 2004b. Evidence of vector-borne disease of Early Cretaceous reptiles. Vector-Borne Zoonotic Dis 4: 281-284.

Poinar Jr GO, Jacobson RL, Eisenberger CL 2006. Early Cretaceous phlebotomine sand fly larvae (Diptera: Psychodidae). Proc Entomol Soc Washington 108: 785-792.

Poinar Jr GO, Lambert JB, Wu Y 2007. Araucarian source of fossiliferous Burmese amber: spectroscopic and anatomical evidence. J Bot Res Inst Texas 1: 449-455.

Schnur, LF, Morsy TF, Githurie JI, Jacobson RL 1992. The status and role of novel trypanosomatids from Egypt and Kenya as parasites of man and animals. Am J Trop Med Hyg 47: 246-247.

Simpson AGB, Stevens JR, Lukes J 2006. The evolution and diversity of kinetoplastid flagellates.Trends Parasitol 22: 168-174.

Sousa MA, Santos SM, Sa-Xavier C, Madeira MF, Cupolillo E, Brazil RP 1998a. Herpetomonas sp. isolated from Nectomys squamypes (Mammalia: Rodentia): molecular, biochemical and morphological characterization. Third International Meeting on Molecular Epidemiology and Evolutionary Genetics of infectious Diseases, Rio de Janeiro, Program with abstracts, p. 85.

Sousa MA, Barrett TV, Naiff RD, Branco DCB, Sá-Xavier C, Santos SM, Cysne L, Brandão A 1998b. Leptomonas sp. isolated from the sandfly Lutzomyia ayrozai (Diptera: Psychodidae). Mem Inst Oswaldo Cruz 93 (Suppl. II): 127.

Steinhaus EA 1949. Principles of Insect Pathology, McGrawHill Book, New York,757 pp.

Vickerman K 2000. Order Kinetoplastea Honigberg, 1963. In JJ Lee, GF Leiedale, P Bradbury, An illustrated Guide to the Protozoa, 2nd ed., Society of Protozoologists, Lawrence, Kansas, p.1159-1180.

Volf P, Kiewegova A, Nemec A 2002. Bacterial colonization in the gut of Phlebotomus duboscqi (Diptera: Psychodidae): transtadial passage and the role of female diet. Folia Parasitol 49: 73-77.

Wallace FG, Hertig M 1968. Ultrastructural comparison of promastigote flagellates (leptomonads) of wild-caught Panamanian Phlebotomus. J Parasitol 53: 66-612.

Warburg A 1991. Entomopathogens of phlebotomine sand flies: laboratory experiments and natural infections. J Invert Pathol 58: 189-202.

Yurchenko VA, Luke J, Jirk M, Zeledon R, Maslov DA 2006. Leptomonas costaricensis sp.n.(Kinetoplastea: Trypanosomatidae), a member of the novel phylogenetic group of insect trypanosomatids closely related to the genus Leishmania. Parasitology 133: 537-546. 
